\title{
The portal-umbilical-iliac-systemic venous shunt in liver cirrhosis
}

\author{
I-Chin Lee, Guang-Xun Xu \\ Hepato-Pancreato-Biliary Center, Beijing Tsinghua Changgung Hospital, Tsinghua University, Beijing, China \\ Correspondence to: Guang-Xun Xu, MD, PhD. Hepato-Pancreato-Biliary Center, Beijing Tsinghua Changgung Hospital, Tsinghua University, No. \\ 168 Li-Tang Road, Beijing 102218, China. Email: drxugx@sina.com.
}

Submitted Sep 17, 2020. Accepted for publication Oct 28, 2020.

doi: $10.21037 / \mathrm{hbsn}-20-715$

View this article at: http://dx.doi.org/10.21037/hbsn-20-715

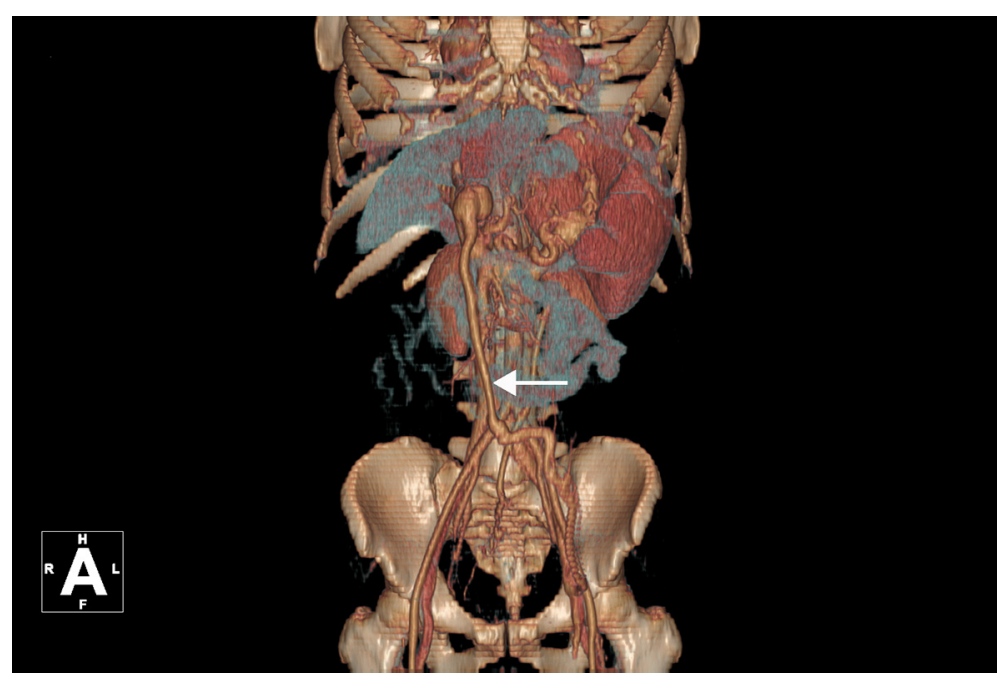

A 45-year-old man with 8-year history of hepatitis B virus related liver cirrhosis presented to the hospital. Physical examination revealed jaundice, severe ascites, umbilical hernia, and caput medusae. Laboratory studies showed a total bilirubin level of $4.14 \mathrm{mg}$ per deciliter (normal range, 0 to 1.52 ), a serum creatinine level of $0.92 \mathrm{mg}$ per deciliter (normal range, 0.64 to 1.09), INR 2.21 (normal range, 0.80 to 1.20 ), Model for End-Stage Liver Disease (MELD) Score was 21 . The 3D reconstruction of CT scans showed a recanalized umbilical vein extending through abdominal wall draining to the left external iliac vein (Panel A, arrow). The patient underwent an orthotopic liver transplantation surgery. During the procedure, the recanalized umbilical vein was carefully dissected and ligated. One month after the transplantation the patient was discharged with well clinical condition and normal liver function. At followup 2 months after surgery, the patient remained well. The umbilical-iliac venous portosystemic shunt can be recognized in liver cirrhotic patients.

\section{Acknowledgments}

We thank Chia-Yung Lee for language editing assistance and Tzu-Hua Lee for technical help.

Funding: None.

\section{Footnote}

Provenance and Peer Review: This article is a standard submission to the editorial office, Hepatobiliary Surgery and Nutrition. The article has undergone external peer review.

Conflicts of Interest: Both authors have completed the ICMJE uniform disclosure form (available at https://hbsn. amegroups.com/article/view/10.21037/hbsn-20-715/coif). The authors have no conflicts of interest to declare. 
Ethical Statement: The authors are accountable for all aspects of the work in ensuring that questions related to the accuracy or integrity of any part of the work are appropriately investigated and resolved. Written informed consent was obtained from the patient for publication of this manuscript and any accompanying images.

Open Access Statement: This is an Open Access article distributed in accordance with the Creative Commons Attribution-NonCommercial-NoDerivs 4.0 International License (CC BY-NC-ND 4.0), which permits the noncommercial replication and distribution of the article with the strict proviso that no changes or edits are made and the original work is properly cited (including links to both the formal publication through the relevant DOI and the license). See: https://creativecommons.org/licenses/by-nc-nd/4.0/.
Cite this article as: Lee IC, Xu GX. The portal-umbilicaliliac-systemic venous shunt in liver cirrhosis. HepatoBiliary Surg Nutr 2021;10(4):585-586. doi: 10.21037/hbsn-20-715 